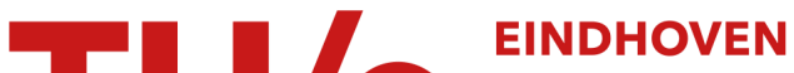 \\ UNIVERSITY OF \\ TECHNOLOGY
}

\section{Self-assembly of hydrogen-bonding gradient copolymers}

\section{Citation for published version (APA):}

Ogura, Y., Artar, M., Palmans, A. R. A., Sawamoto, M., Meijer, E. W., \& Terashima, T. (2017). Self-assembly of hydrogen-bonding gradient copolymers: sequence control via tandem living radical polymerization with transesterification. Macromolecules, 50(8), 3215-3223. https://doi.org/10.1021/acs.macromol.7b00070

DOI:

10.1021/acs.macromol.7b00070

Document status and date:

Published: 25/04/2017

\section{Document Version:}

Accepted manuscript including changes made at the peer-review stage

\section{Please check the document version of this publication:}

- A submitted manuscript is the version of the article upon submission and before peer-review. There can be important differences between the submitted version and the official published version of record. People interested in the research are advised to contact the author for the final version of the publication, or visit the $\mathrm{DOI}$ to the publisher's website.

- The final author version and the galley proof are versions of the publication after peer review.

- The final published version features the final layout of the paper including the volume, issue and page numbers.

Link to publication

\section{General rights}

Copyright and moral rights for the publications made accessible in the public portal are retained by the authors and/or other copyright owners and it is a condition of accessing publications that users recognise and abide by the legal requirements associated with these rights.

- Users may download and print one copy of any publication from the public portal for the purpose of private study or research.

- You may not further distribute the material or use it for any profit-making activity or commercial gain

- You may freely distribute the URL identifying the publication in the public portal.

If the publication is distributed under the terms of Article 25fa of the Dutch Copyright Act, indicated by the "Taverne" license above, please follow below link for the End User Agreement:

www.tue.nl/taverne

Take down policy

If you believe that this document breaches copyright please contact us at:

openaccess@tue.nl

providing details and we will investigate your claim. 


\title{
Hydrogen-Bonding Gradient Copolymers: Sequence Control via Tandem Living Radical Polymerization with Transesterification and Folding/Aggregation Properties
}

Yusuke Ogura, ${ }^{1}$ Takaya Terashima, ${ }^{1 *}$ Müge Artar, ${ }^{2}$ Anja R. A. Palmans, ${ }^{2}$ Mitsuo Sawamoto, ${ }^{1 *}$ E. W. Meijer $^{2 *}$

${ }^{1}$ Department of Polymer Chemistry, Graduate School of Engineering, Kyoto University, Katsura, Nishikyoku, Kyoto 615-8510, JAPAN, Tel/Fax: +81-75-383-2603

E-mail: terashima@living.polym.kyoto-u.ac.jp, sawamoto@star.polym.kyoto-u.ac.jp

${ }^{2}$ Laboratory of Macromolecular and Organic Chemistry and Institute for Complex Molecular Systems, Eindhoven University of Technology, P.O. Box 513, 5600 MB Eindhoven, The Netherlands

*Corresponding Author

\begin{abstract}
Chiral 1,3,5-tricarboxamide (BTA)-functionalized copolymers with gradient, bidirectional gradient, and random sequence distributions were synthesized via tandem living radical polymerization (LRP) with in-situ monomer transesterification to investigate the effects of the BTA sequence on self-folding/aggregation properties in organic media. Here, 2-ethylhexyl methacrylate (EHMA) as a starting monomer was polymerized with a ruthenium catalytic system in the presence of a chiral BTA-bearing alcohol $(\mathrm{BTA}-\mathrm{OH})$ and $\mathrm{Ti}(\mathrm{O} i-\mathrm{Pr})_{4} . \quad$ By tuning the concentration and time of addition of the Ti catalyst, the transesterification rate of EHMA into a chiral BTA-functionalized methacrylate (BTAMA) was synchronized with LRP to produce EHMA/BTAMA gradient or bidirectional gradient copolymers. In contrast, faster transesterification than LRP gave the corresponding random copolymer. Circular dichroism spectroscopy and dynamic light scattering performed on solutions of all BTA-functionalized copolymers indicated that the chiral BTA pendants helically self-assemble via hydrogen-bonding interaction in 1,2-dichloroethane, methylcyclohexane $(\mathrm{MCH})$, and their mixtures to form single-chain or multi-chain polymeric nanoparticles. The temperature-dependent self-assembly behavior of the BTA pendants was virtually independent of the sequence distribution, whereas the size of the resultant nanoparticles depended on the sequence as follows: random < bidirectional random < gradient in $\mathrm{MCH}$.
\end{abstract}




\section{Introduction}

The marriage of precision polymerization and supramolecular self-assembly opens up new avenues which permit to obtain functional polymeric materials with well-defined three-dimensional architectures. Single-chain polymeric nanoparticles (SCPNs) and related unimer micelles and nanoaggregates ${ }^{1-27}$ are now attracting increasing attention as these compartmentalized polymers show promise in mimicking functions of natural biopolymers such as proteins and enzymes. ${ }^{13,18}$ SCPNs are often constructed by the self-folding of functional and/or amphiphilic "random" copolymers via physical interaction. Hereby, they dynamically and reversibly form globular structures that are responsive to stimuli or environmental changes. ${ }^{10-21}$ The intramolecular folding process is triggered by the site-specific self-assembly of the functional pendants via non-covalent interactions (e.g. hydrogen-bond, coordination, host-guest ${ }^{10-19}$ and/or autonomous self-assembly of the amphiphilic main chains or pendants in water or specific solvents. ${ }^{12,13,20,21}$ Thus, selective formation of desired SCPNs requires the precision control of the primary structure (e.g., molecular weight: chain length, composition, monomer sequence) by living polymerization, ${ }^{12,20,21}$ in addition to the design of the functional pendants.

Among them, chiral benzene-1,3,5-tricarboxamide (BTA)-functionalized random copolymers are promising scaffolds to self-fold or self-assemble into SCPNs in organic or aqueous media. ${ }^{11-13}$ Similar to "free" BTA derivatives, ${ }^{28-34}$ the chiral BTA pendants induce helical self-assembly via strong three-fold hydrogen bonding interaction. Resultant SCPNs contain helical secondary structures within their globular tertiary structure; this feature has encouraged us to design enzymelike polymer catalysts with well-defined nanospaces. ${ }^{13}$ To understand the internal structure of BTAbased SCPNs, the BTA helical stacking process in chain folding was investigated by temperaturedependent circular dichroism (CD) spectroscopy. ${ }^{11-13}$ The elongation temperature of the pendant BTA units is dependent on the local concentration along a chain, i.e., BTA composition, while it is independent of the total concentration of the BTA in solutions. ${ }^{11,13 \mathrm{a}}$ This is characteristic of the intramolecular self-assembly of the BTA units within a single macromolecule. The BTA pendants do not undergo cooperative self-assembly, in contrast to "free" (non polymer-supported) BTA derivatives. Such non-cooperative self-assembly is attributed to the formation of segregated and multiple helical stacks of the pendant BTAs within SCPNs, as inferred from "Sergeant-and-Soldiers" experiments with BTA-functionalized random block copolymers. ${ }^{11 \mathrm{c}}$ However, to date the folding and self-assembly processes have always been studied using BTA pendants "randomly" distributed along the polymer chain. The question remains if the BTA-sequence distribution along a polymer chain has an effect on the degree of BTA self-assembly and polymer chain folding/aggregation. 
We herein report the precision synthesis of BTA-functionalized copolymers which differ in monomer sequence distributions, namely gradient, bidirectional gradient, and randomly distributed, and investigate the consequences of the BTA sequence on self-folding/aggregation properties in organic media (Scheme 1). BTA-functionalized gradient copolymers are of particular interest because the local concentration of BTA pendants gradually increases from one terminal to another along a polymer chain. Such a biased sequence distribution of BTA units may lead to polymer chain folding and/or BTA self-assembly that differs from its random counterpart.

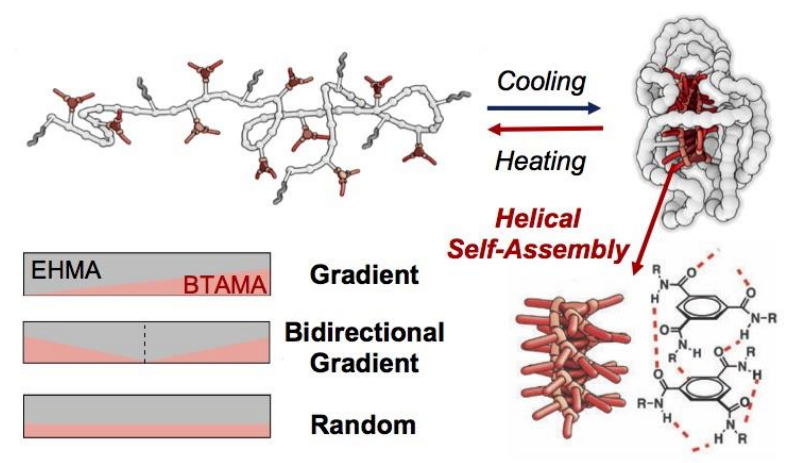

Scheme 1. Self-folding and self-assembly of BTA-functionalized copolymers with different sequence distribution.

A series of BTA sequence-controlled copolymers was prepared by tandem catalysis of ruthenium-catalyzed living radical polymerization (LRP) $)^{35,36}$ and metal alkoxide-mediated transesterification of methacrylates with alcohols (Scheme 2). ${ }^{37,38}$ This system is effective to design various gradient copolymers because the gradient sequence and composition can be catalytically controlled by tuning the synchronization efficiency of LRP and in-situ transesterification of monomers. Thus, the controllability of sequence distribution is better than the conventional two methods: 1) living polymerization of two monomers with different reactivity and 2) living polymerization via continuous addition of a second monomer. ${ }^{39-42}$

2-Ethylhexyl methacrylate (EHMA) as a starting monomer was polymerized with a ruthenium catalytic system $\left[\mathrm{Ru}(\mathrm{Ind}) \mathrm{Cl}\left(\mathrm{PPh}_{3}\right)_{2} / n-\mathrm{Bu}_{3} \mathrm{~N}\right]$ and a chloride initiator in the presence of a chiral BTAfunctionalized alcohol (BTA-OH), and $\operatorname{Ti}(\mathrm{O} i-\mathrm{Pr})_{4}$. The selection of EHMA is due to the high solubility of resulting copolymers in organic media such as 1,2-dichroloethane (DCE) or methyl cyclohexane $(\mathrm{MCH})$. EHMA was concurrently transesterified with BTA-OH and the Ti catalyst into a chiral BTA-functionalized methacrylate (BTAMA) during LRP by modulating concentration and additional timing of the $\mathrm{Ti}$ catalyst. As a result, a synchronized transesterification with polymerization occurred to give a EHMA/BTAMA gradient copolymer whose BTA composition 
gradually increased from the initiating terminal to the growing counterpart. Synchronized tandem catalysis using a bifunctional initiator further led to a EHMA/BTAMA bidirectional gradient copolymer, where BTA composition gradually increased from the center of the chain to both terminals. In contrast, faster transesterification than LRP provided a EHMA/BTAMA random copolymer. The self-folding and self-assembly properties of EHMA/BTAMA gradient, bidirectional gradient, and random copolymers were further evaluated by temperature-dependent CD measurement and dynamic light scattering (DLS). All of the copolymers efficiently induce hydrogen-bonding helical self-assembly of the BTA pendants to form SCPNs and/or multi-chain nanoaggregates in DCE, MCH, and mixtures of these solvents. The sequence distribution mainly affects the size distribution of resulting SCPNs and nanoaggregates.

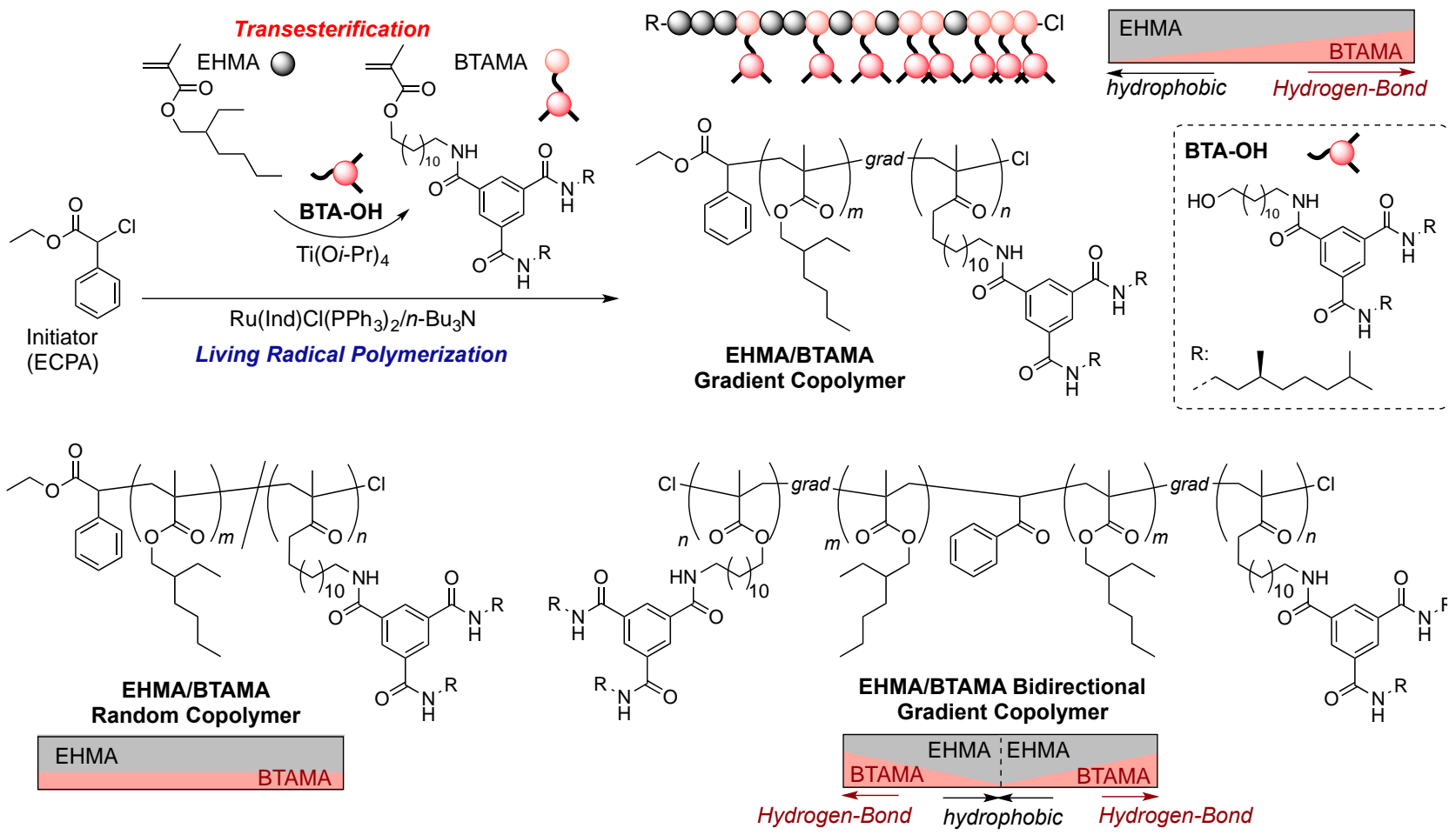

Scheme 2. EHMA/BTAMA gradient, random, and bidirectional gradient copolymers via concurrent tandem catalysis of ruthenium-catalyzed living radical polymerization and in-situ monomer transesterification.

\section{Results and Discussion}

\section{Synthesis of EHMA/BTAMA Gradient and Random Copolymers by Tandem Polymerization}

To begin with, the transesterification of EHMA $(1000 \mathrm{mM})$ was investigated with $\mathrm{Ti}(\mathrm{O} i \text { - } \mathrm{Pr})_{4}$ (20 $\mathrm{mM})$ and $\mathrm{N}$-(6-hydroxyhexyl)benzamide $(250 \mathrm{mM})$ as a model alcohol of BTA-OH in 1,4- 
dioxane at $80^{\circ} \mathrm{C}$ (Scheme 3). 1,4-Dioxane was employed to efficiently solubilize the amide-bearing alcohol. EHMA was efficiently transesterified into a corresponding methacrylate. The conversion of EHMA reached $10 \%$ in $17 \mathrm{~h}$, giving $100 \mathrm{mM}$ of the product (confirmed by ${ }^{1} \mathrm{H} \mathrm{NMR}$ ). This indicates that Ti-mediated transesterification is compatible with EHMA and amide-functionalized alcohols and products. ${ }^{43,44}$

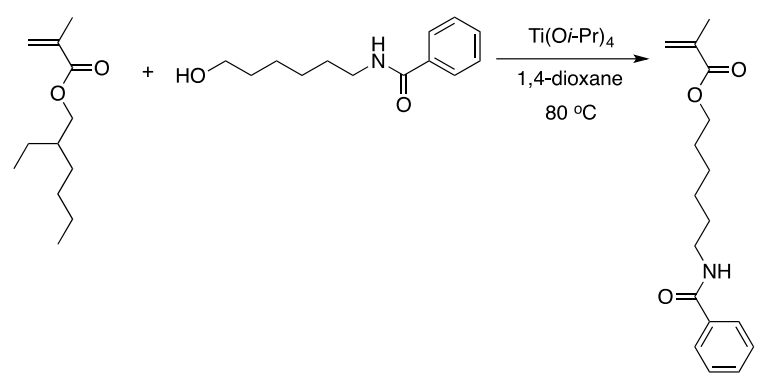

Scheme 3. Transesterification of EHMA with $N$-(6-hydroxyhexyl)benzamide in 1,4-dioxane.

Given the model study, we examined the synthesis of EHMA/BTAMA gradient and random copolymers via concurrent tandem catalysis of LRP and in-situ transesterification. The target BTAMA content was set at around 10 mol\% because 10 mol\% BTAMA-functionalized random copolymers have been often utilized to investigate self-folding properties in aqueous and organic media. ${ }^{11-13}$ The formation of gradient copolymers requires kinetic synchronization of LRP and transesterification. ${ }^{37,38}$ We thus carried out tandem polymerization of EHMA with BTA-OH by changing the concentration of $\mathrm{Ti}(\mathrm{O} i-\mathrm{Pr})_{4}$ catalyst between 8 and $20 \mathrm{mM}$, and by changing the time of catalyst addition (immediately, after $2 \mathrm{~h}$ or after $4 \mathrm{~h}$ ) (Figure 1, Table 1).

Table 1. Synthesis of MMA/BTAMA Copolymers via Concurrent Tandem Living Radical Polymerization $^{a}$

\begin{tabular}{cccccccc}
\hline Code & $\begin{array}{c}{\left[\mathrm{Ti}(\mathrm{O} i \text {-Pr })_{4}\right]} \\
(\mathrm{mM})\end{array}$ & $\begin{array}{c}\text { Time } \\
(\mathrm{h})\end{array}$ & $\begin{array}{c}\mathrm{Conv}^{b} \\
(\%)\end{array}$ & $\begin{array}{c}M_{\mathrm{n}}{ }^{c} \\
(\mathrm{GPC})\end{array}$ & $M_{\mathrm{w}} / M_{\mathrm{n}}{ }^{c}$ & $\begin{array}{c}M_{\mathrm{n}}{ }^{d} \\
(\mathrm{NMR})\end{array}$ & $\begin{array}{c}{\text { EHMA/BTAMA } / i-\text { PrMA }^{e}} \\
(\%)\end{array}$ \\
\hline P1 & 8 & 23 & 74 & 45000 & 1.34 & 52700 & $92.1 / 7.5 / 0.4$ \\
$\mathbf{P 2}$ & 15 & 24 & 80 & 36800 & 1.52 & 48800 & $88.6 / 8.8 / 2.6$ \\
$\mathbf{P 3}$ & 20 & 23 & 76 & 36200 & 1.43 & 47600 & $86.6 / 9.3 / 4.1$ \\
$\mathbf{P 4}$ & 8 & 28 & 83 & 43700 & 1.35 & 49400 & $91.8 / 7.7 / 0.5$ \\
\hline
\end{tabular}

${ }^{a}[$ EHMA $] /[$ ECPA $\quad($ P1-P3 $)$ or $\quad$ DCAP $\quad(\mathbf{P 4})] /\left[\mathrm{Ru}(\operatorname{Ind}) \mathrm{Cl}\left(\mathrm{PPh}_{3}\right)_{2}\right] /\left[\mathrm{Ti}(\mathrm{O} i-\mathrm{Pr})_{4}\right] /\left[n-\mathrm{Bu}_{3} \mathrm{~N}\right] /[\mathrm{BTA}-\mathrm{OH}] \quad=$ $1000 / 5 / 1 / 8,15$, and $20 / 20 / 120 \mathrm{mM}$ in 1,4-dioxane at $80{ }^{\circ} \mathrm{C}$. $\mathrm{Ti}(\mathrm{O} i \text {-Pr })_{4}$ catalyst was pre-loaded before polymerization (P3) or added to the polymerization solutions after $2 \mathrm{~h}(\mathbf{P 2})$ or $4 \mathrm{~h}(\mathbf{P 1}, \mathbf{P 4}) .{ }^{b}$ Total monomer conversion determined by ${ }^{1} \mathrm{H}$ NMR using an internal standard (tetralin). ${ }^{c}$ Determined by SEC in THF with PMMA standard calibration. ${ }^{d}$ Number-average molecular weight determined by ${ }^{1} \mathrm{H}$ NMR. ${ }^{e}$ Copolymer composition ( $\mathrm{mol} \%$ ) determined bv ${ }^{1} \mathrm{H}$ NMR. 


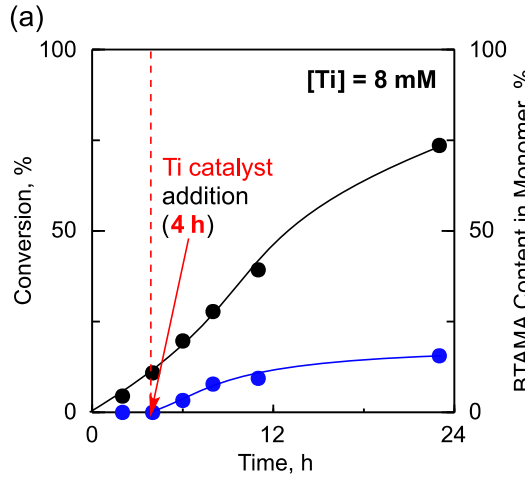

(d)

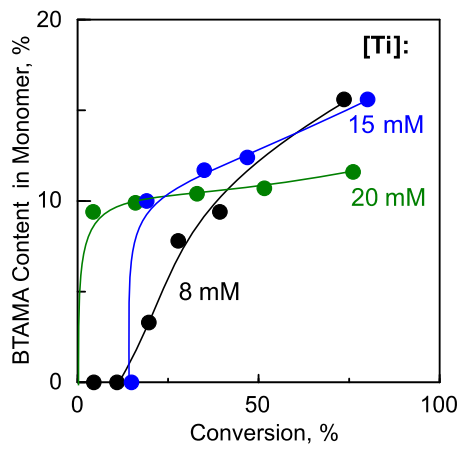

(b)

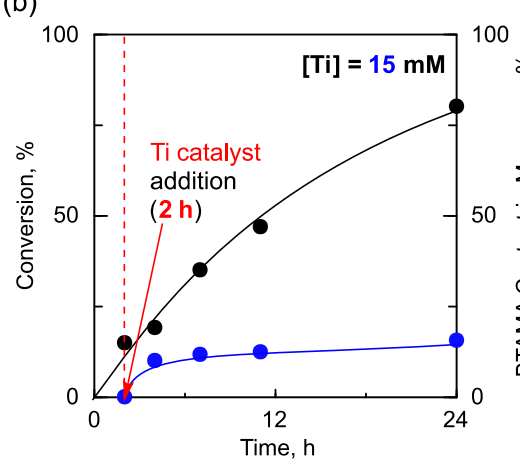

(e)

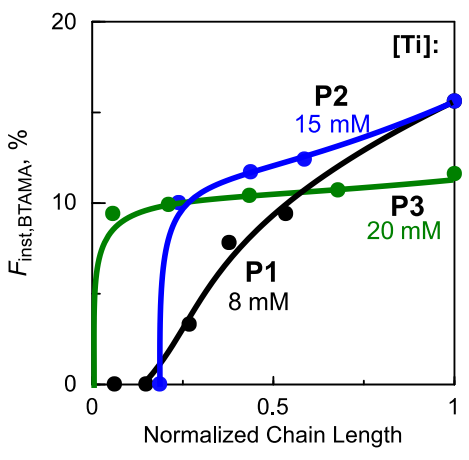

(c)

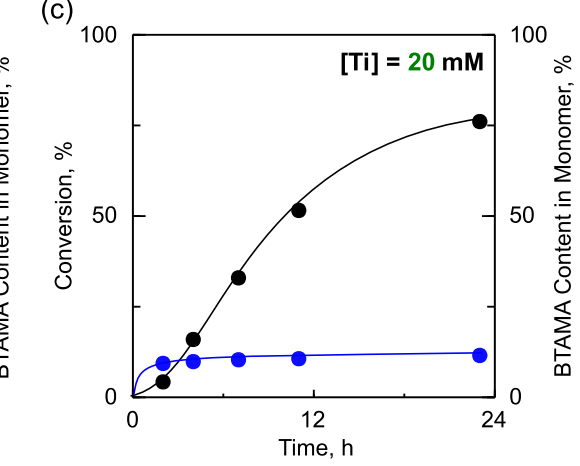

(f)

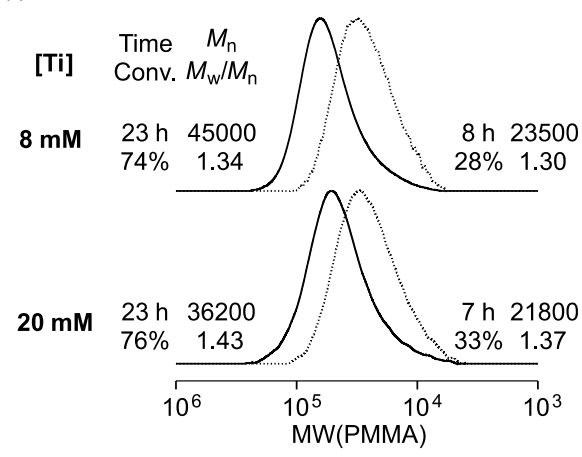

Figure 1. Synthesis of EHMA/BTAMA copolymers (P1 - P3) via concurrent tandem catalysis of LRP and in-situ transesterification: [EHMA]/[ECPA]/[Ru(Ind)Cl( $\left.\left.\mathrm{PPh}_{3}\right)_{2}\right] /\left[\mathrm{Ti}(\mathrm{O} i \text {-Pr })_{4}\right] /\left[n-\mathrm{Bu}_{3} \mathrm{~N}\right] /$ $\left[\right.$ BTA-OH] = 1000/5/2/8 (P1), $15(\mathbf{P 2})$, and $20(\mathbf{P 3}) / 20 / 120 \mathrm{mM}$ in 1,4-dioxane at $80{ }^{\circ} \mathrm{C}$. (a-c) Total monomer conversion and BTAMA content in monomer; $(\mathrm{a}, \mathrm{b})$ 1,4-dioxane solutions of $\mathrm{Ti}(\mathrm{O} i \text { - } \mathrm{Pr})_{4}$ catalyst were added to polymerization solutions at (a) $4 \mathrm{~h}$ or (b) $2 \mathrm{~h}$ under argon. (d) BTAMA content in monomer as a function of total conversion. (e) Instantaneous BTAMA composition in copolymers as a function of normalized chain length. (f) SEC curves of products obtained with 8 or $20 \mathrm{mM}$ Ti.

EHMA was polymerized with $\mathrm{Ru}(\mathrm{Ind}) \mathrm{Cl}\left(\mathrm{PPh}_{3}\right)_{2}$ catalyst and a chloride initiator (ECPA) in the presence of $n-\mathrm{Bu}_{3} \mathrm{~N}$ cocatalyst (for $\left.\mathrm{LRP}\right), \mathrm{Ti}(\mathrm{O} i-\mathrm{Pr})_{4}$ catalyst (for transesterification), and BTA-OH as alcohol in 1,4-dioxane at $80^{\circ} \mathrm{C}$ (Figure 1c). Aiming at the formation of about $10 \mathrm{~mol} \%$ BTAMA, we used a relatively small amount of BTA-OH (120 mM) with EHMA (1000 mM). The in-situ generation of BTAMA was monitored by ${ }^{1} \mathrm{H}$ NMR measurement of the polymerization solutions that were sampled at predetermined periods (Figure S1). The conversion of total monomers (all methacrylate bonds: EHMA and generating BTAMA) and the BTAMA content in the monomer [BTAMA/(EHMA+BTAMA)] are plotted as a function of reaction time (Figure 1c).

To synchronize in-situ transesterification with LRP for gradient copolymers, we added $\mathrm{Ti}(\mathrm{O} i$ $\mathrm{Pr})_{4}$ into polymerization solutions after starting LRP of EHMA. The Ti catalyst concentration was 
set as 8 or $15 \mathrm{mM}$ (Figure 1a,b). A delay in the addition of $\mathrm{Ti}(\mathrm{O} i \text { - } \mathrm{Pr})_{4}$ allows skipping the induction period of LRP. In fact, synchronized transesterification with LRP was successfully achieved by adding $8 \mathrm{mM}$ Ti catalyst at $4 \mathrm{~h}$ after starting LRP (Figure 1a). The BTAMA content in the monomer linearly increased with increasing monomer conversion (Figure 1d, black line). The synchronized catalysis efficiently produced well-controlled EHMA/BTAMA gradient copolymers with narrow molecular weight distribution $\left(\mathbf{P 1}: M_{\mathrm{n}}=45000, M_{\mathrm{w}} / M_{\mathrm{n}}=1.34\right)$. Instantaneous BTAMA content in polymer $\left(F_{\text {inst,BTAMA }}\right)$ was estimated with BTAMA composition in monomer (Figure 1d), assuming that EHMA and BTAMA have simlar reactivities in the copolymerization. $F_{\text {inst,BTAMA }}$ gradually increased from $0 \%$ to $16 \%$ along the polymer chain (Figure 1e, black line). Delayed addition of 15 $\mathrm{mM}$ Ti catalyst at $2 \mathrm{~h}$ also gave a EHMA/BTAMA gradient copolymer $(\mathbf{P 2})$, whereas $F_{\text {inst,BTAMA }}$ quickly increased from 0 to $10 \%$ after addition of Ti and then slowly increased to $16 \%$ (Figure 1e, blue line). This is because the fast transesterification takes place even if the addition of the Ti catalyst is delayed.

Isolated EHMA/BTAMA gradient copolymers, P1 and the intermediate (conv. = 39\%), were further analyzed by ${ }^{1} \mathrm{H}$ NMR (Figure 2). Both samples exhibited methylene protons adjacent to BTA amide group ( $c: 3.6-3.0 \mathrm{ppm}$ ), aromatic protons of BTA units ( $d: 8.3 \mathrm{ppm})$, and methylene protons adjacent to ester pendants $(a, b: 4.1-3.6 \mathrm{ppm})$, in addition to aromatic protons of the initiator fragment ( $e: 7.3-7.1 \mathrm{ppm}$ ), methylene and methyl protons of methacrylate backbone and BTAMA alkyl pendants. Cumulative BTAMA content in polymer ( $\left.F_{\text {cum. BTAMA }}\right)$ was estimated from the area ratio of peak $c$ and peak $a+b[c / 3(a+b)] . \quad F_{\text {cum,BTAMA }}$ of $\mathbf{P 1}$ and the intermediate was determined to

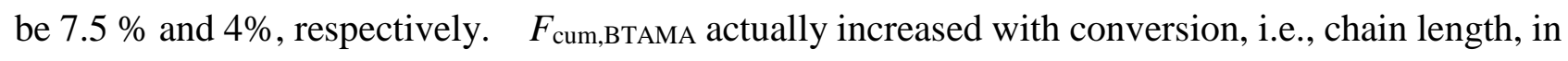
sharp contrast to that of $\mathbf{P 3}$. This result supports that $\mathbf{P 1}$ is a gradient copolymer whose BTAMA composition gradually increased from the initiating terminal to growing counterpart.

We further conducted the tandem polymerization with $\mathrm{Ti}(\mathrm{O} i-\mathrm{Pr})_{4}$ of $20 \mathrm{mM}$ without the delayed addition of the $\mathrm{Ti}$ catalyst; all reagents including the $\mathrm{Ti}$ catalyst were charged before the reaction. EHMA was immediately transesterified into BTAMA much faster than copolymerization of EHMA and the generating BTAMA. The content of BTAMA in monomer already saturated at $10 \%$ during the induction period of LRP (Figure 1c,d). As a result, this condition provided a EHMA/BTAMA random copolymer $\left(\mathbf{P 3}: M_{\mathrm{n}}=36200, M_{\mathrm{w}} / M_{\mathrm{n}}=1.43\right.$, by size exclusion

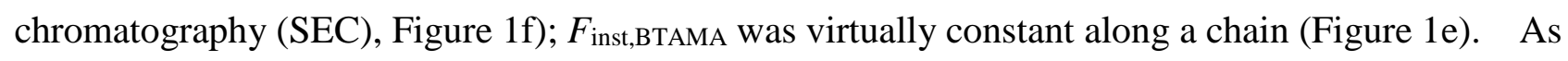
shown by ${ }^{1} \mathrm{H}$ NMR measurement of isolated $\mathbf{P 3}$ and the intermediate (Figure S2), the cumulative BTA content in the copolymers was almost constant $\left(F_{\text {cum,BTAMA }}=8-9\right.$ mol\% $)$, and independent of the chain length. 


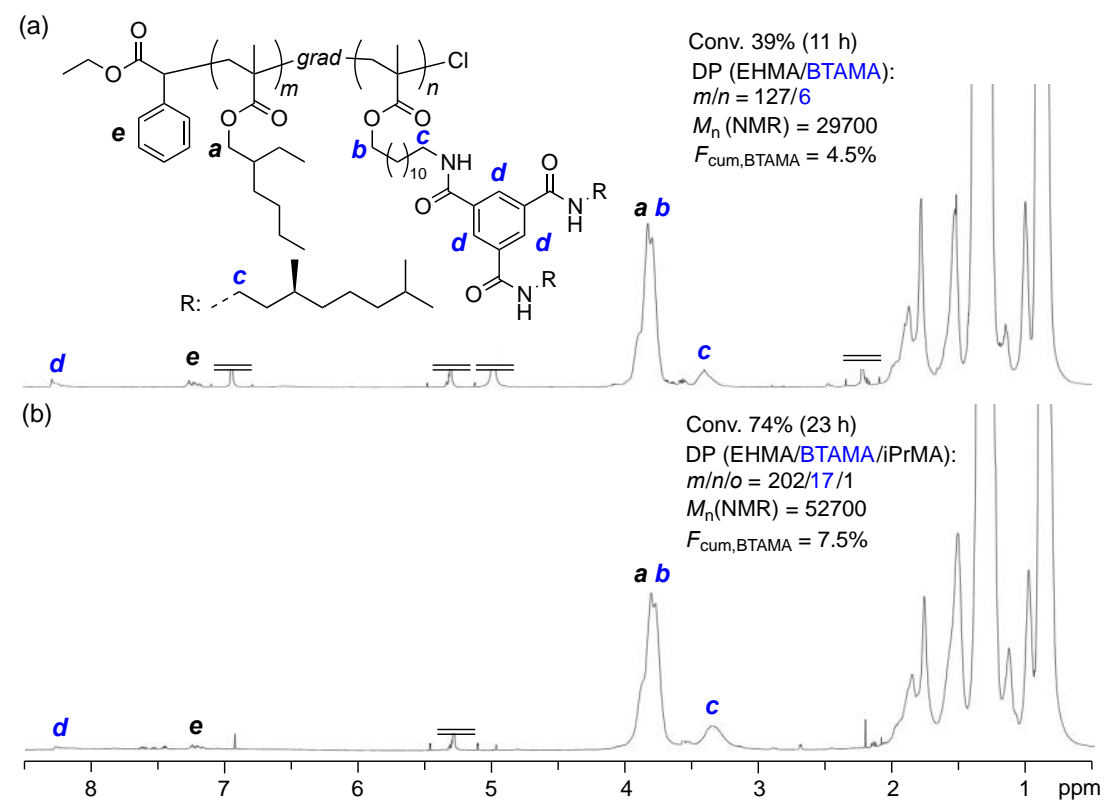

Figure 2. ${ }^{1} \mathrm{H}$ NMR spectra of EHMA/BTAMA copolymers in $\mathrm{CD}_{2} \mathrm{Cl}_{2}$ at $25{ }^{\circ} \mathrm{C}$ : (b) $\mathbf{P 1}$ (74\% conversion, $23 \mathrm{~h}$ ); (a) the intermediate at $39 \%$ conversion $(11 \mathrm{~h})$.

\section{Synthesis of Bidirectional EHMA/BTAMA Gradient Copolymers}

Performing the tandem catalysis with a bifunctional initiator, dichloroacetophenone (DCAP), instead of monofunctional ECPA is an effective way to obtain bidirectional gradient copolymers, in which the monomer composition gradually changes from the central part of the polymer chains to both terminals. ${ }^{38 \mathrm{~b}}$ The synthesis of a EHMA/BTAMA bidirectional gradient copolymer was thus examined by tandem living radical polymerization of EHMA with DCAP and BTA-OH in 1,4dioxane at $80{ }^{\circ} \mathrm{C}$ (Figure 3). We applied the same conditions and $\mathrm{Ti}(\mathrm{O} i \text {-Pr })_{4}$ addition technique as those optimized for P1: Ti(Oi-Pr $)_{4}(8 \mathrm{mM})$ was added into LRP solution of EHMA $4 \mathrm{~h}$ after starting the polymerization. Synchronized tandem catalysis of transesterification and LRP again took place (Figure 3a), and the BTAMA content in the monomer linearly increased with the total monomer conversion (Figure 3b). SEC and ${ }^{1} \mathrm{H}$ NMR indicated that a well-controlled EHMA/BTAMA bifunctional gradient copolymer was obtained $\left(\mathbf{P 4}: M_{\mathrm{n}}=43700, M_{\mathrm{w}} / M_{\mathrm{n}}=1.35\right.$, Figures $3 \mathrm{~cd}$ and S3). These results demonstrate that our tandem catalysis of LRP and transesterification efficiently affords the sequence control of hydrogen-bonding BTAMA units in copolymers by tuning Ti catalyst concentration, additional timing of Ti catalyst, and initiators. 

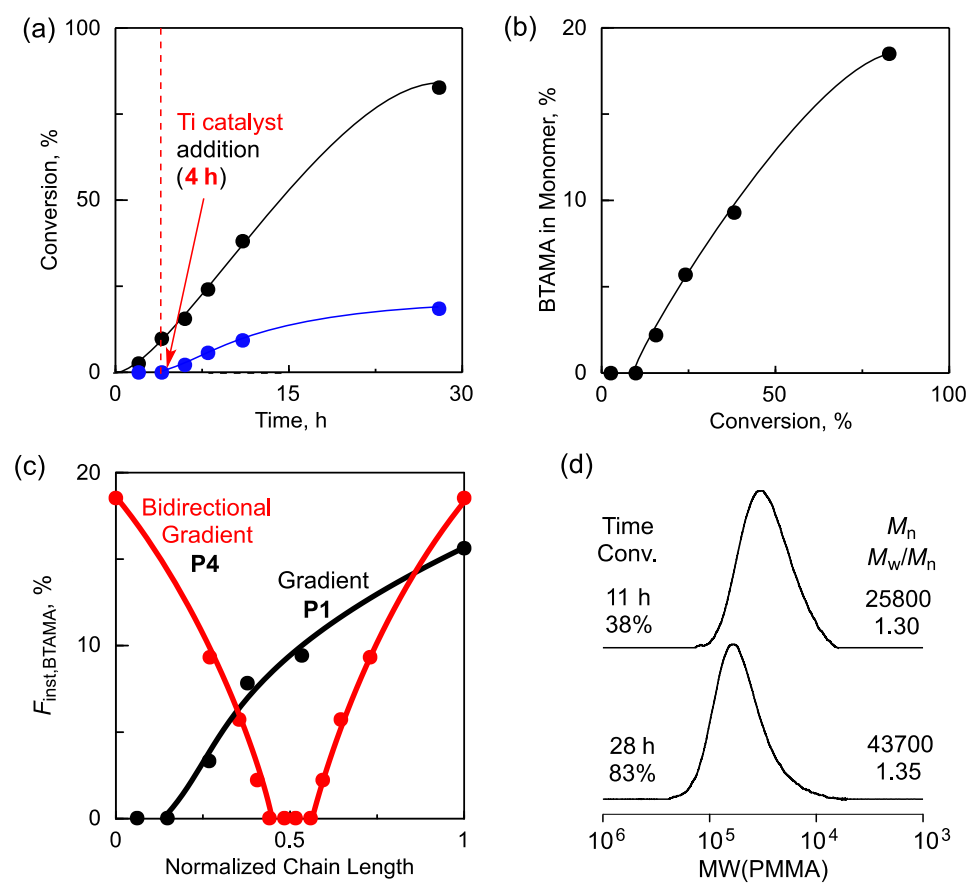

Figure 3. Synthesis of a EHMA/BTAMA bifunctional gradient copolymer (P4) via concurrent tandem catalysis: [EHMA]/[DCAP]/[Ru(Ind)Cl( $\left.\left(\mathrm{PPh}_{3}\right)_{2}\right] /\left[\mathrm{Ti}(\mathrm{O} i-\mathrm{Pr})_{4}\right] /[n-\mathrm{Bu} 3 \mathrm{~N}] /[\mathrm{BTA}-\mathrm{OH}]=$ $1000 / 5 / 2 / 8 / 20 / 120 \mathrm{mM}$ in 1,4 -dioxane at $80{ }^{\circ} \mathrm{C}$. (a) Total monomer conversion and BTAMA content in monomer; a 1,4-dioxane solution of $\mathrm{Ti}(\mathrm{O} i \text { - } \mathrm{Pr})_{4}$ was added to the polymerization solution at $4 \mathrm{~h}$ under argon. (b) BTAMA content in monomer as a function of total conversion. (c) Instantaneous BTAMA composition of $\mathbf{P 4}$ or P1 as a function of normalized chain length. (d) SEC curves of the products

\section{Self-Assembly and Self-Folding of EHMA/BTAMA Sequence-Controlled Copolymers}

BTAMA-based copolymers often intramolecularly fold or intermolecularly self-assemble to form single-chain polymeric nanoparticles or multi-chain aggregates, respectively, via the helical self-assembly of the chiral BTA pendants by hydrogen-bonding interaction in halogenated or hydrocarbon solvents. ${ }^{11}$ It was previously shown that the local BTA content (BTA composition) in the polymers strongly affects the BTA self-assembly and chain-folding/aggregation properties. ${ }^{11-13}$ In contrast, the effects of the sequence distribution of the BTA units along a polymer chain on the properties have not yet been explored. We thus evaluated self-folding/aggregation properties of P1 - P4 by using circular dichroism (CD) spectroscopy and dynamic light scattering (DLS) in 1,2dichloroethane (DCE), methylcyclohexane (MCH), and its mixtures. Importantly, the four polymer samples consist of different monomer sequence distribution (gradient, random, and bidirectional gradient) but have almost identical BTAMA content $\left(F_{\text {cum,BTAMA }}=\sim 10 \%\right)$ and degree of 
polymerization. Here, helical self-assembly behavior of the chiral BTA pendants was evaluated by CD spectroscopy, while the size of the resulting single-chain or multi-chain polymeric nanoparticles was determined by DLS.

BTA Self-assembly. $\quad$ P1 - P4 were analyzed by CD spectroscopy in DCE or MCH at $25{ }^{\circ} \mathrm{C}$ $([\mathrm{BTA}]=50 \mu \mathrm{M})$. Prior to analysis, the polymers were homogeneously solubilized in their solvents by sonication for 5 hours at room temperature. As typically shown in Figure 4 (sample: P1), all of the samples clearly showed negative Cotton effect originating from helical self-assembly of the chiral BTA pendants $\left(\lambda_{\max }=223 \mathrm{~nm}\right)$ in both DCE and MCH. In all cases, the CD intensity in MCH was larger than that in DCE, indicating that $\mathrm{MCH}$ enhanced the self-assembly of the pendant BTA more than DCE.

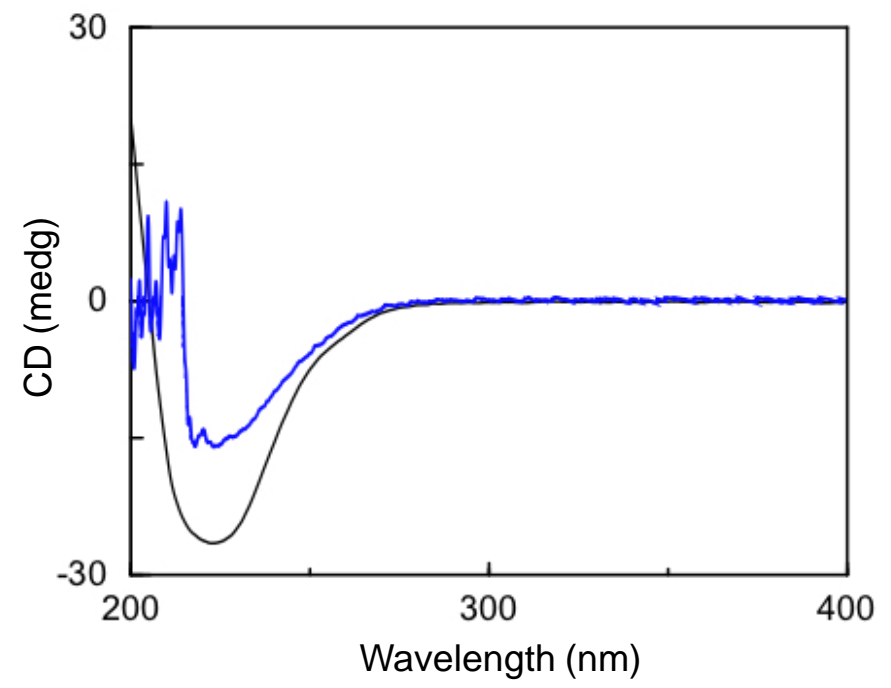

Figure 4. $\mathrm{CD}$ spectra of $\mathbf{P 1}$ in 1,2-dichloroethane (blue) or methylcyclohexane (black) at $25{ }^{\circ} \mathrm{C}$ : $(\lambda=200-400 \mathrm{~nm},[\mathrm{BTA}]=50 \mu \mathrm{M}, l=0.5 \mathrm{~cm})$.

To investigate the effects of solvents and temperature on self-assembly of the BTA pendants, temperature-dependent $\mathrm{CD}$ measurements of $\mathbf{P 1}$ were conducted in $\mathrm{DCE}, \mathrm{MCH}$, and DCE/MCH mixed solvents $\left(75 / 25,50 / 50,25 / 75\right.$, v/v) by cooling from $80{ }^{\circ} \mathrm{C}$ to $0{ }^{\circ} \mathrm{C}$ (Figure 5a). In DCE, the solution was $\mathrm{CD}$ silent at $80{ }^{\circ} \mathrm{C}$ but the $\mathrm{CD}$ effect gradually appeared starting from around $60{ }^{\circ} \mathrm{C}$ by cooling and finally reached a value of -24 mdeg at $0{ }^{\circ} \mathrm{C}$. Similarly, P1 showed a gradual increase of negative Cotton effect by cooling in $\mathrm{DCE} / \mathrm{MCH}$ mixtures and $\mathrm{MCH}$ alone. The intensity increased with increasing $\mathrm{MCH}$ content in the temperature range between 0 and $80^{\circ} \mathrm{C}$. Interestingly, P1 still exhibited large negative Cotton effect (-22 mdeg) at $80{ }^{\circ} \mathrm{C}$ in $\mathrm{MCH}$, indicating that $\mathbf{P 1}$ can effectively maintain self-assembly of the BTA pendants even at such a high temperature. The molar ellipticity $(\Delta \varepsilon)$ for $\mathbf{P 1}$ in DCE, DCE/MCH $\left(75 / 25\right.$, v/v), and $\mathrm{MCH}$ at $20{ }^{\circ} \mathrm{C}$ was $-22,-22$, and $-32 \mathrm{~L}$ $\mathrm{mol}^{-1} \mathrm{~cm}^{-1}$, respectively. These values are relatively close to those for ABA or ABC random triblock 
copolymers functionalized with BTA in the B segment and other hydrogen-bonding units in the A segment in similar organic media $\left(\Delta \varepsilon=-23--30 \mathrm{~L} \mathrm{~mol}^{-1} \mathrm{~cm}^{-1}\right) .{ }^{11 \mathrm{~b}, 11 \mathrm{~d}}$
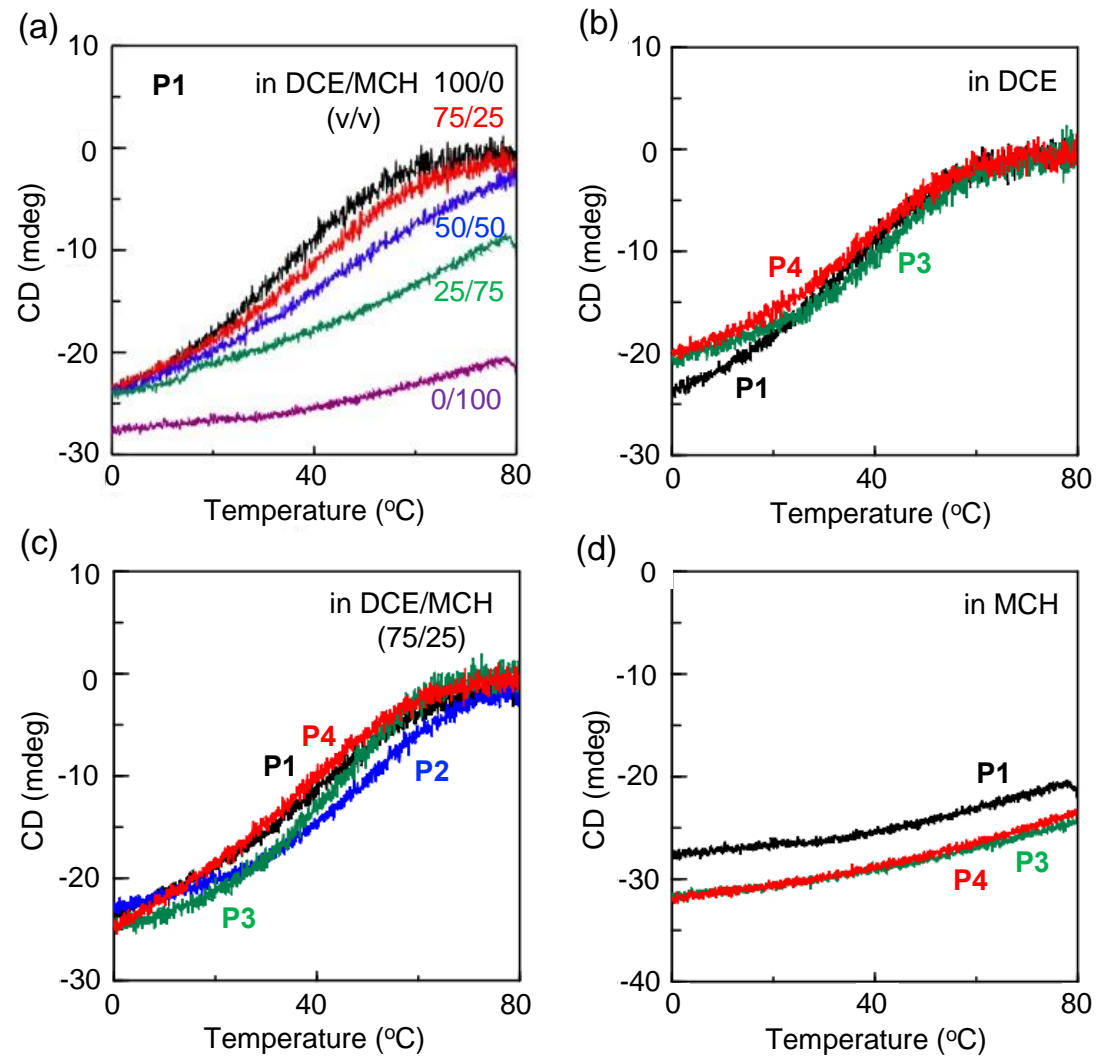

Figure 5. Temperature-dependent CD cooling curves of EHMA/BTAMA copolymers (P1-P4) in organic solvents $([\mathrm{BTA}]=50 \mu \mathrm{M}, l=0.5 \mathrm{~cm})$ at a cooling rate of $60 \mathrm{~K} \mathrm{~h}^{-1}$ on probed at $\lambda=223 \mathrm{~nm}$. (a) $\mathbf{P 1}$ in 1,2-dichloroethane $(\mathrm{DCE})$, methylcyclohexane $(\mathrm{MCH})$, and mixed solvents $(\mathrm{DCE} / \mathrm{MCH}=$ 100/0, 75/25, 50/50, 25/75, 0/100, v/v). (b, d) P1, P3, and P4 in (b) DCE or (d) MCH. (c) P1, P2, P3, and $\mathbf{P 4}$ in DCE/MCH $(75 / 25, \mathrm{v} / \mathrm{v})$.

We further conducted temperature-dependent CD measurement of P2, P3, and P4 in DCE, $\mathrm{MCH}$, and a DCE/MCH mixture (75/25, v/v) to clarify the effects of BTA-sequence distribution on self-assembly of the BTA pendants. P1 (linear gradient), P3 (random), and P4 (bidirectional gradient) showed similar shapes of the CD cooling curves and CD intensity in DCE (Figure 5b). The molar ellipticity $(\Delta \varepsilon)$ for P1, P3, and P4 in DCE at $20{ }^{\circ} \mathrm{C}$ was $-22,-21$, and $-19 \mathrm{~L} \mathrm{~mol}^{-1} \mathrm{~cm}^{-1}$, respectively. The elongation temperature of the BTA pendants into helical self-assembly was about $60{ }^{\circ} \mathrm{C}$, and was independent of the BTA sequence distribution. A similar trend in CD intensity was also observed in $\mathrm{MCH}$ or DCE/MCH (75/25) mixture; the intensity in $\mathrm{MCH}$ was largest (Figure 5c,d). These results importantly suggest that the total BTA unit number capable of helical self-assembly is in fact independent of the random or gradient sequence of $10 \mathrm{~mol} \%$ BTAMA. In gradient copolymers (P1 and P4), a BTAMA-rich segment in polymer chain can efficiently induce helical 
self-assembly of the pendants, while a BTAMA-poor segment in turn can hardly contribute the selfassembly. Additionally, P1 and $\mathbf{P 4}$ have the instantaneous BTAMA content ( $\left.F_{\text {inst,BTAMA }}\right)$ of 16 and $19 \%$, respectively, at the most. They further consist of relatively long polymer chain of $200 \mathrm{DP}$. As a result, $\mathbf{P 1}$ and $\mathbf{P 4}$ of such a BTA-gradient distribution would have almost identical efficiency of BTA-pendant self-assembly to $\mathbf{P 3}$ of homogeneous (random) counterpart. The self-assembly of BTA pendants for gradient copolymers (P1 and P4) did not undergo a cooperative process, similar to that for a random counterpart (P3) and several BTA-functionalized random copolymers as already reported. ${ }^{11-13}$ In DCE/MCH mixture (75/25, v/v), P2 maintained negative Cotton effects at higher temperature than P3 (Figure 5c). This is because the local BTA concentration in P2 is higher than that in P3. ${ }^{11,12,13 a}$ The negative Cotton effect of $\mathbf{P 2}$ at $0{ }^{\circ} \mathbf{C}$ was, however, almost identical to that of P1, P3, and P4 (Figure 5c). Thus, in relatively long polymer chains of $200 \mathrm{DP}$ comprising $10 \mathrm{~mol} \%$ BTA units, the sequence distribution, random or gradient, does not significantly affect the selfassembly behavior of the BTA pendants.

Aggregation Properties. EHMA/BTAMA gradient, random, and bidirectional gradient copolymers (P1, P3, and P4) were further analyzed by DLS in DCE, MCH, and a DCE/MCH (75/25, v/v) mixed solvent at $25{ }^{\circ} \mathrm{C}$ (Figure 6, Table 2). In DCE, P1 and P3 showed bimodal size distributions comprising particles with a small size $\left(R_{\mathrm{h}}=\sim 10 \mathrm{~nm}\right)$ and with a larger size $\left(R_{\mathrm{h}}=\sim 100\right.$ $\mathrm{nm}$ ) (Figure 6a). The former originate from SCPNs or nanoaggregates comprising a small number of polymers, while the latter are attributed to multi-chain aggregates. The small size portion of $\mathbf{P 1}$ $\left(R_{\mathrm{h}}=\sim 10 \mathrm{~nm}\right)$ increased upon heating to $60{ }^{\circ} \mathrm{C}$. This demonstrates that aggregated polymer chains are dynamically isolated into single polymer chains by disruption of hydrogen-bonding self-assembly
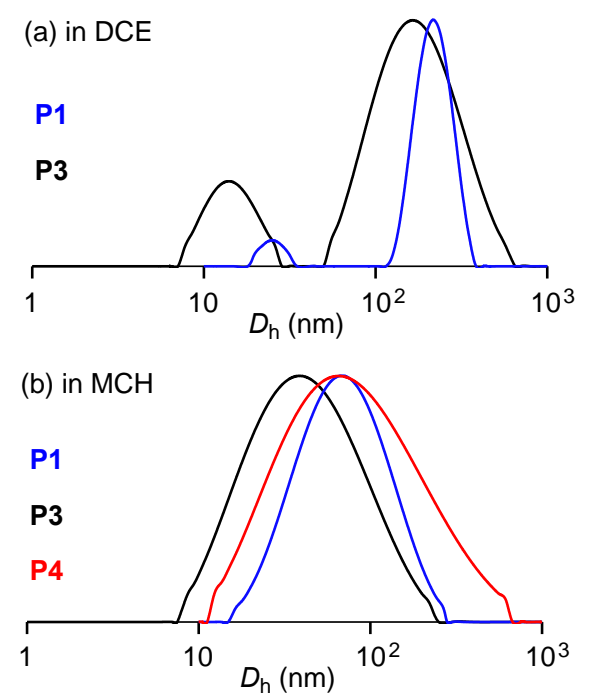

Figure 6. DLS intensity size distribution of EHMA/BTAMA copolymers (P1, P3, and P4) in (a) DCE or (b) $\mathrm{MCH}$ at $25{ }^{\circ} \mathrm{C}$ : [Polymer] $=1 \mathrm{mg} / \mathrm{mL}$. 
of BTA-pendants upon heating. This is consistent with the lack of a Cotton effect of P1 in DCE at $60{ }^{\circ} \mathrm{C}$ (Figure 5b). In a DCE/MCH (75/25, v/v) mixed solvent, P1 showed a bimodal size distribution, and the volume fraction of the small size portion $\left(R_{\mathrm{h}}=6.2 \mathrm{~nm}: 40 \%\right)$ was larger than that in DCE alone (Table 2). In contrast to the results in DCE, P1, P3, and P4 showed a single, monomodal size distribution $\left(R_{\mathrm{h}}=26-55 \mathrm{~nm}\right)$ in $\mathrm{MCH}$ at $25{ }^{\circ} \mathrm{C}$, indicating the presence of multichain aggregates (Figure 6b). $\quad \mathbf{P 1}$ and $\mathbf{P 4}$ with gradient sequence $\left(\mathbf{P 1}: R_{\mathrm{h}}=40 \mathrm{~nm}, \mathbf{P 4}: R_{\mathrm{h}}=55 \mathrm{~nm}\right)$ formed nanoaggregates larger than those of the corresponding random copolymer $\left(\mathbf{P 3}: R_{\mathrm{h}}=26 \mathrm{~nm}\right)$. This is probably because locally concentrated BTA pendants of P1 and P4 promote intermolecular self-assembly of the polymer chains to provide relatively large aggregates. Therefore, the sequence distribution of BTA units mainly affects the aggregation behavior of the polymer chains and the total size of resulting aggregates.

Table 2. Hydrodynamic Radius of EHMA/BTAMA Copolymers ${ }^{\mathrm{a}}$

\begin{tabular}{cccc}
\hline entry & polymer & solvent & $\begin{array}{c}R_{\mathrm{h}} \\
(\mathrm{nm})\end{array}$ \\
\hline 1 & P1 & DCE & $13(25 \%), 111(75 \%)$ \\
2 & P1 & DCE/MCH $(75 / 25, \mathrm{v} / \mathrm{v})$ & $6.2(40 \%), 128(60 \%)$ \\
3 & P1 & MCH & 40 \\
4 & P3 & DCE & $7.4(9 \%), 97(91 \%)$ \\
5 & P3 & MCH & 26 \\
6 & P4 & MCH & 55
\end{tabular}

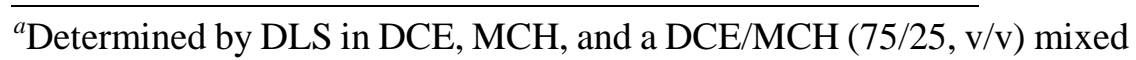
solvent at $25^{\circ} \mathrm{C}$ : [polymer] $=1 \mathrm{mg} / \mathrm{mL}$.

\section{Conclusion}

Sequence-controlled copolymers with hydrogen-bonding chiral BTA pendants were successfully synthesized by tandem catalysis of Ru-catalyzed LRP and Ti-mediated transesterification with BTA-OH. Transesterification using $\mathrm{Ti}(\mathrm{O} i \text {-Pr })_{4}$ was compatible with an amide-functionalized alcohol to afford the catalytic control of introducing a hydrogen-bonding monomer sequence in copolymers. Ti-mediated transesterification of EHMA with BTA-OH was efficiently synchronized with LRP of EHMA and a generating BTAMA by tuning the concentration and addition time of the Ti catalyst, giving a well-controlled EHMA/BTAMA gradient copolymer. Additionally, synchronized tandem catalysis with a bifunctional initiator provided a EHMA/BTAMA bidirectional gradient copolymer, while transesterification faster than LRP resulted in a EHMA/BTAMA random copolymer. A series of BTA sequence-controlled copolymers efficiently formed single-chain polymeric nanoparticles or multi-chain aggregates via the helical self-assembly 
of the chiral BTA pendants in DCE, MCH, and their mixtures. In all cases, the self-assembly of BTA pendants was enhanced in $\mathrm{MCH}$ and maintained up to high temperatures $\left(80^{\circ} \mathrm{C}\right)$. Importantly, the total size and/or size distribution of single-chain or multi-chain nanoparticles was dependent on BTAMA sequence distribution, although temperature-dependent self-assembly behavior of the chiral BTA pendants was independent of the sequence. Typically, BTAMA gradient or bidirectional gradient copolymers formed nanoaggregates larger than the corresponding random copolymer in $\mathrm{MCH}$, indicating that gradient sequence of BTA pendants would efficiently promote the intermolecular self-assembly of polymer chains. Thus, we revealed that gradient incorporation of hydrogen-bonding self-assembly units along chains is also one option to control the structure and size of nanoaggregates in organic media. 


\section{ASSOCIATED CONTENT}

\section{Supporting Information}

The Supporting Information is available free of charge on the ACS Publications website.

Experimental details, ${ }^{1} \mathrm{H}$ NMR of polymers (file type, i.e., PDF)

\section{AUTHOR INFORMATION}

\section{Corresponding Author}

*E-mail: terashima@living.polym.kyoto-u.ac.jp (T.T).

*E-mail: sawamoto@star.polym.kyoto-u.ac.jp (M. S.)

*E-mail: e.w.meijer@tue.nl (E.W.M.)

\section{Notes}

The authors declare no competing financial interest.

\section{ACKNOWLEDGMENT}

This research was supported by the Ministry of Education, Science, Sports and Culture through Grants-in-Aid for Scientific Research (A: 24245026; C: 26410134), by Mizuho Foundation for the Promotion of Sciences, by The Sumitomo Foundation (131302), and by Research Institute for Production Development, for which T.T. is grateful. MA, ARAP and EWM gratefully acknowledge financial support from The Netherlands Organization for Scientific Research (ECHO Grant 713.011.001) and the Dutch Ministry of Education, Culture and Science (Gravity program 024.001.035). 


\section{References}

1) Mavila, S.; Eivgi, O.; Berkovich, I.; Lemcoff, N. G. Chem. Rev. 2016, 116, 878-961.

2) Ouchi, M.; Badi, N.; Lutz, J.-F.; Sawamoto, M. Nat. Chem. 2011, 3, 917-924.

3) Li, L.; Raghupathi, K.; Song, C.; Prasad, P.; Thayumanavan, S. Chem. Commun. 2014, 50, 13417-13432.

4) (a) Hanlon, A. M. Lyon, C. K. Berda, E. B. Macromolecules 2016, 49, 2-14. (b) Lyon, C. K.; Prasher, A.; Hanlon, A. M.; Tuten, B. T.; Tooley, C. A.; Frank, P. G.; Berda, E. B. Polym. Chem. 2015, 6, 181- 197.

5) (a) Altintas, O.; Barner-Kowollik, C. Macromol. Rapid Commun. 2016, 37, 29-46. (b) Altintas, O.; Barner-Kowollik, C. Macromol. Rapid Commun. 2012, 33, 958-971.

6) (a) Gonzalez-Burgos, M.; Latorre-Sanchez, A.; Pomposo, J. A. Chem. Soc. Rev. 2015, 44, 61226142. (b) Pomposo, J. A. Polym. Int. 2014, 63, 589-592.

7) Artar, M.; Huerta, E.; Meijer, E. W.; Palmans, A. R. A. ACS Symp. Ser. 2014, 1170, 313-325.

8) (a) Terashima, T. Polym. J. 2014, 46, 664-673. (b) Terashima, T.; Sawamoto, M. ACS Symp. Ser. 2014, 1170, 255-267.

9) Seo, M.; Beck, B. J.; Paulusse, J. M. J.; Hawker, C. J.; Kim, S. Y. Macromolecules 2008, 41, 6413-6418.

10) (a) Foster, E. J.; Berda, E. B.; Meijer, E. W. J. Am. Chem. Soc. 2009, 131, 6964-6966. (b) Stals, P. J. M.; Gillissen, M. A. J.; Nicolay, R.; Palmans, A. R. A.; Meijer, E. W. Polym. Chem. 2013, 4, 2584-2597.

11) (a) Mes, T.; van der Weegen, R.; Palmans, A. R. A.; Meier, E. W. Angew. Chem. Int. Ed. 2011, 50, 5085-5089. (b) Hosono, N.; Gillissen, M. A. J.; Li, Y.; Sheiko, S. S.; Palmans, A. R. A.; Meijer, E. W. J. Am. Chem. Soc. 2013, 135, 501-510. (c) Hosono, N.; Palmans, A. R. A.; Meijer E. W. Chem. Commun. 2014, 50, 7990-7993. (d) Altintas, O.; Artar, M.; ter Huurne, G.; Voets, I. K.; Palmans, A. R. A.; Barner-Kowollik, C.; Meijer, E. W. Macromolecules 2015, 48, 89218932.

12) (a) Gillissen, M. A. J.; Terashima, T.; Meijer, E. W.; Palmans, A. R. A; Voets, I. K. Macromolecules 2013, 46, 4120-4125. (b) Stals, P. J. M.; Gillissen, M. A. J.; Paffen, T. F. E.; de Greef, T. F. A.; Lindner, P.; Meijer, E. W.; Palmans, A. R. A.; Voets, I. K. Macromolecules 2014, 47, 2947-2954.

13) (a) Terashima, T.; Mes, T.; de Greef, T. F. A.; Gillissen, M. A. J.; Besenius, P.; Palmans, A. R. A.; Meijer, E. W. J. Am. Chem. Soc. 2011, 133, 4742-4745. (b) Artar, M.; Souren, E. R. J.; Terashima, T.; Meijer, E. W.; Palmans, A. R. A. ACS Macro Lett. 2015, 4, 1099-1103. (c) Liu, Y.; Pauloehrl, T.; Presolski, S. I.; Albertazzi, L.; Palmans, A. R. A.; Meijer, E. W. J. Am. Chem. 
Soc. 2015, 137, 13096-13105.

14) Altintas, O.; Lejeune, E.; Gerstel, P.; Barner-Kowollik, C. Polym. Chem. 2012, 3, 640-651.

15) Romulus, J.; Weck, M. Macromol. Rapid Commun. 2013, 34, 1518-1523.

16) Willenbacher, J.; Altintas, O.; Trouillet, V.; Knöfel, N.; Monteiro, M. J.; Roesky, P. W.; BarnerKowollik, C. Polym. Chem. 2015, 6, 4358-4365.

17) Mavila, S.; Rozenberg, I.; Lemcoff, N. G. Chem. Sci. 2014, 5, 4196-4203.

18) Sanchez-Sanchez, A.; Arbe, A.; Kohlbrecher, J.; Colmenero, J.; Pomposo, J. A. Macromol. Rapid. Commun. 2015, 36, 1592-1597.

19) Appel, E. A.; Dyson, J.; del Barrio, J.; Walsh, Z.; Scherman, O. A. Angew. Chem. Int. Ed. 2012, $51,4185-4189$.

20) Morishima, Y.; Nomura, S.; Ikeda, T.; Seki, M.; Kamachi, M. Macromolecules 1999, 32, 74697475 .

21) (a) Terashima, T.; Sugita, T.; Fukae, K.; Sawamoto, M. Macromolecules 2014, 47, 589-600. (b) Matsumoto, K.; Terashima, T.; Sugita, T.; Takenaka, M.; Sawamoto, M. Macromolecules 2016, 49, 7917-7927. (c) Koda, Y.; Terashima, T.; Sawamoto, M. Macromolecules 2016, 49, 45344543. (d) Hirai, Y.; Terashima, T.; Takenaka, M.; Sawamoto, M. Macromolecules 2016, 49, 5084-5091.

22) Croce, T. A.; Hamilton, S. K.; Chen, M. L.; Muchalski, H.; Harth, E. Macromolecules 2007, 40, 6028-6031.

23) Cherian, A. E.; Sun, F. C.; Sheiko, S. S.; Coates, G. W. J. Am. Chem. Soc. 2007, 129, 1135011351.

24) Murray, B. S.; Fulton, D. A. Macromolecules 2011, 44, 7242-7252.

25) Chao, D.; Jia, X.; Tuten, B.; Wang, C.; Berda, E. B. Chem. Commun. 2013, 49, 4178-4180.

26) Song, C.; Li, L.; Dai, L.; Thayumanavan, S. Polym. Chem. 2015, 6, 4828-4834.

27) Wong, E. H. H.; Qiao, G. G. Macromolecules 2015, 48, 1371-1379.

28) Matsunaga, Y.; Miyajima, N.; Nakayasu, Y.; Sakai, S.; Yonenaga, M. Bull. Chem. Soc. Jpn. 1988, 61, 207-210

29) Yasuda, Y.; Iishi, E.; Inada, H.; Shirota, Y. Chem. Lett. 1996, 7, 575-576.

30) Sakamoto, A.; Ogata, D.; Shikata, T.; Hanabusa, K. Macromolecules 2005, 38, 8983-8986.

31) de Loos, M.; van Esch, J. H.; Kellogg, R. M.; Feringa, B. L. Tetrahedron 2007, 63, 7285-7301.

32) Blomenhofer, M.; Ganzleben, S.; Hanft, D.; Schmidt, H.-W.; Kristiansen, M.; Smith, P.; Stoll, K.; Maeder, D.; Hoffmann, K. Macromolecules 2005, 38, 3688-3695.

33) (a) van Gorp, J. J.; Vekemans, J. A. J. M.; Meijer, E. W. J. Am. Chem. Soc. 2002, 124, 1475914769. (b) Roosma, J.; Mes, T.; Leclère P.; Palmans, A. R. A.; Meijer, E. W. J. Am. Chem. Soc. 2008, 130, 1120-1121. (c) Gillissen, M. A. J.; Koenigs, M. M. E.; Spiering, J. J. H.; Vekemans, 
J. A. J. M.; Palmans, A. R. A.; Voets, I. K.; Meijer, E. W. J. Am. Chem. Soc. 2014, 136, 336343.

34) (a) Smulders, M. M. J.; Filot, I. A. W.; Leenders, J. M. A.; van der Schoot, P.; A. R. A. Palmans.; Schenning, A. P. H. J.; E. W. Meijer. J. Am. Chem. Soc. 2010, 132, 611-619. (b) Y. Nakano.; T. Hirose.; P. J. M. Stals.; E. W. Meijer.; A. R. A. Palmans. Chem. Sci. 2012, 3, 148-155.

35) Ouchi, M.; Terashima, T.; Sawamoto, M. Chem. Rev. 2009, 109, 4963-5050.

36) (a) Matyjaszewski, K. Macromolecules 2012, 45, 4015-4039. (b) Matyjaszewski, K.; Tsarevsky, N. V. J. Am. Chem. Soc. 2014, 136, 6513-6533.

37) (a) Nakatani, K.; Terahsima, T.; Sawamoto, M. J. Am. Chem. Soc. 2009, 131, 13600-13601. (b) Nakatani, K.; Ogura, Y.; Koda, Y.; Terashima, T.; Sawamoto, M. J. Am. Chem. Soc. 2012, 134, 4373-4383.

38) (a) Ogura, Y.; Terashima, T.; Sawamoto, M. ACS Maco Lett. 2013, 2, 985-989. (b) Ogura, Y.; Terashima, T.; Sawamoto, M. Macromolecules submitted.

39) Matyjaszewski, K.; Ziegler, M. J.; Arehart, S. V.; Greszta, D.; Pakula, T. J. Phys. Org. Chem. 2000, 13, 775-786.

40) Park, J-S.; Kataoka, K. Macromolecules 2006, 39, 6622-6630.

41) Kim, J.; Mok, M. M.; Sandoval, R. W.; Woo, D. J.; Torkelson, J. M. Macromolecules 2006, 39, 6152-6160.

42) Seno, K.; Tsujimoto, I.; Kanaoka, S.; Aoshima, S. J. Polym. Sci. Part A: Polym. Chem. 2008, 46, 6444-6454.

43) Rehwinkel, H.; Steglich, W. Synthesis 1982, 826-827.

44) Krasik, P. Tetrahedron Lett. 1998, 39, 4223-4226. 
Table of Contents Image

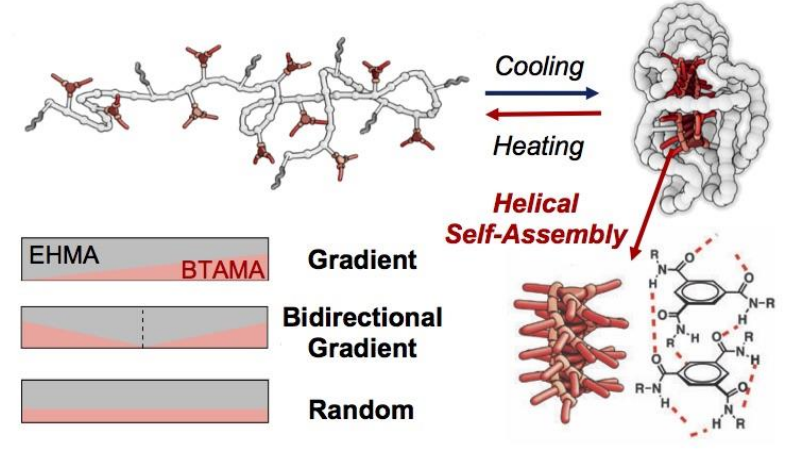

